\title{
THE SEARCH FOR A SATISFACTORY CULTURE. TRENDS IN ARCHAEO- ASTRONOMY DURING THE SOVIET PERIOD IN ESTONIA
}

\section{Mare Kõiva}

\begin{abstract}
Research and fieldwork in archaeo-astronomy from the 1960s to the 1990s in Estonia coincided with the national movement there, thus helping to create a satisfying perception of history and national identity during the Soviet period. Myths, folklore and mythological motifs were associated with the prehistoric sky and reckoning of time; the calendar, time reckoning, sacred sites, and rock drawings were studied, symbols and marks were decoded. The fine arts and documental works making use of similar themes achieved a high level of expressive power that had an influence on mentality and culture, even outside of Estonia. At the centre of this movement were many charismatic individuals. Research, which was interdisciplinary in its nature, took place outside the framework of existing institutions, as a result of which the choice of fields of study, the manner of approach and resulting interpretations were much freer.
\end{abstract}

Keywords: archaeo-astronomy, Heino Eelsalu, folklore, Lennart Meri, myths, national identity, rock art, socialism

As David Lowenthal in his provocative works has stated - "Heritage is not a testable or even plausible version of our past; it is a declaration of faith in that past" (Lowenthal 1996: 121, 1998). Similarities with declaration of faith can also be found in areas of scholarly research and essayistic writing. One cannot conduct experiments the results of which are reproducible or provable with religious beliefs, nor can one expect such beliefs to exhibit any logical structure. They do, however, provide some level of security. When scholarship functions this way, the message it contains is much more important than absolute knowledge. Research presenting an interpretation of past traditions, such as the treatment of prehistory and archaeo (palaeo)-astronomy, as well as works of art inspired by a search for the roots of their own culture and a more genuine world view, played a similar role in Estonia during the Soviet period. 
According to Juri Lotman (1991) the effect a phenomenon has on culture after its realization is all the stronger the more unexpected it is. Every new text as it enters an existing space inevitably changes it. The very nature of the totalitarian Soviet regime left individuals and whole peoples without a dignified sense of history. A characteristic feature of Soviet-style socialism was a vast difference between oral history within the home circle and received history found in scholarly publications. The trivialisation and marginalization of Estonian history as well as its selective presentation created a deficit just as noticeable as the lack of other goods and knowledge of facts. Writing on the topic of a national history that had been fragmented and expunged helped recreate a more whole perception of history; it compensated for the distorted version of history and the censored versions of the past.

Archaeo-astronomy, the subject of the present article, can be defined as a branch of science that tries to uncover and interpret the connections between human-made monuments, symbols, patterns, rituals and astronomy. It also describes ancient observatories, systems of time reckoning and calendars as well as how astronomical events have been reflected in culture (see Iwanisczewski 1994). In Estonia this discipline, under the initiative of Heino Eelsalu, was called palaeo-astronomy. However, in the present study we will prefer the term used in Europe and America. It must be noted that the majority of phenomena discussed here are objects within the larger public domain and their degree of generalisation and value is higher than objects within individual domains. As such, their symbolic value within society as a whole is also higher.

Characteristically of this discipline, similar cultural universals in different locations around the world are sought out, and the social meaning and mentality behind such material objects are reconstructed. Archaeo-astronomy preferably attempts to interpret the more distant past, with the assumption that the wealth of meaning inherent in the objects under scrutiny has some relevance to present-day culture. As an umbrella-term various sub-disciplines are subsumed under it. Among these, ethno-astronomy - in Estonia a branch of folklore studies - deals primarily with traditional folk astronomy, such as the names of stars, related beliefs and tales. 
The results of archaeo-astronomical research by Estonians according to discipline in Estonia and among the other peoples belonging to the Finno-Ugric language family from the beginning of the 20th century to the beginning of the 21 st century have already been outlined in a collection of articles from the 10th annual conference of the European Society for Astronomy in Culture (SEAC) (Kõiva and Vesik 2005). This collection also points out the perspectives for potential future research in the field, taking into account those resources that are available to researchers in digitalised form and that provide an opportunity for making considerable progress in terms of generalisations. Preliminary results in many such areas and themes are already available; still lacking are overviews critically evaluating the sources or in-depth analyses.

The present article is based on the above-mentioned and examines more closely how, within the context of rigidly delineated possibilities, interdisciplinary cooperation was able to thrive in the form of field work, conferences, literature and art that had a significant effect on the cultural space in Estonia. The various fields that were influenced by the treatment of archaeo-astronomy will be described as well as the gaps that these served to fill within the research at that time. We will look for an answer to the question of why no dialogue was opened up between a discipline which managed to create a huge interest among readers by talented creative scholars and artists and the spheres of scholarship that were being officially financed at that time. From the late 50s of the 20th century up to the past decade archaeo-astronomy played a significant role in Estonian society. It managed to connect professionals with wide-ranging interests from many different disciplines and countless amateurs, whose contributions forwarded the study of myths and the classical fields of archaeo-astronomy. The direction the research took was similar to the ethnically motivated movements taking place at the same time. As a result, we will also examine what effect did the research have on the development of a national sense of being Estonian. I believe that beyond the concrete contribution made to folklore, archaeology, history and the interpretations made from archaeo-astronomy - unfortunately, these works have not been critically evaluated yet by scholars from individual disciplines - more important is what they were able to contribute to the cultural situation, spirit and unofficial ideology of the time. Anthony Wallace 
writes that when a foreign regime pushes an indigenous population from active participation into making political decisions, "a concious, deliberate effort on the part of some members of society to create a more satisfying culture" (Wallace 1985: 319). By giving meaning to myths and natural phenomena this informal grouping in Estonia managed to create a symbolic strategy for their own nationality. In other words they created "a narrative concerning [their] historic origins, the comings and goings of the group" (Cohen 1974: 98).

\section{RESEARCH TRENDS IN THE FIRST HALF OF THE 20TH CENTURY}

For progress to be made in any given field of study it is necessary first to organise the system and understand the principles behind its functioning. Over the past century exciting descriptions and theories about astral myths have continued to enthral readers. These have presented Estonian folk religion as a collation of perceptions, flights of fancy and rules. At the same time new perspectives on the myths, folklore and the earlier stages of Estonian history have also been presented. Over the past hundred years folk astronomy and the folk calendar, the reckoning of time, sacred sites as well as mythology and folklore have been officially recognised fields of study (see in more detail Kõiva \& Vesik 2005).

The earlier facts of ethno-astronomy have been described in great detail in the thorough works of Jakob Hurt (1898), Paul-Egon Prüller (1968) and Andres Kuperjanov (2003). Each of these sets of writings concludes a certain period in this field of study. Jakob Hurt summarized the known ethno-astronomical facts at the end of the 19th century. Being interested in astronomy, he compiled a systematic overview of Estonian folk astronomy which was based on written sources, his own knowledge as well as the results of surveys answered by nearly 1,500 local informants. He also hinted at the possibility of finding similar material in Estonian poetic folklore without actually managing to arrive at this stage. Paul-Egon Prüller concentrated on the names of stars. He connected the knowledge found in folk traditions with the official astronomical names of the stars and the map of the sky. J. Hurt's presentation, his earlier manu- 
scripts and publications, as well as newer materials, which had been collected and stored in the Estonian folklore archives during the first half of the 20th century, provided the source for Prüller's article. However, he avoided using information about folk beliefs and poetic texts. Prüller's writing provided a significant base of knowledge for building an outline of archaeo-astronomy and finding connections between ideas. Andres Kuperjanov's collection of material extends into the 21st century. Here he examines the relevant system of beliefs, relics of astral mythology and astral motifs found in poetic folklore. But more importantly, in his presentation he focuses his attention on the connection between ethno-astronomy and social movements. He presents the results of the research by Heino Eelsalu, a well-known Estonian scholar in the field of the history of science. The influences of the archaeo-astronomic movement can also be seen in his work.

Significant contributions in the field of astral mythology in the middle of the last century were also made by the folklorists Matthias Johann Eisen and Oskar Loorits. Unfortunately, the works of these two individuals reached only a small number of compatriots. The Second World War severed the philological continuity. A large number of eminent scholars in the humanities emigrated, and those that remained in their homeland were repressed while several scholars changed their field of study. Contacts between the exile community and the homeland were made complicated. Very many individuals were prohibited from visiting their homeland, and many did not risk coming because they were afraid of endangering their lives or those of their relatives. The availability of material and books was curtailed. During the period of censorship at the end of the 1940s the names of many émigrés and so-called undesirable individuals were erased or even physically cut out from the materials available in public libraries. Their books and many other periodic publications were placed in special stacks, where this material could be used only with special permission. In particular this affected works published in pre-war Estonia.

Matthias Johann Eisen's works were not to be found in all libraries even though, in principle, they were publicly available. In his overviews of astral beliefs (Eisen 1919) he describes phenomena in their complexity and points out their similarities primarily to Ger- 
man traditions. However, he does not distinguish general features from infrequently occurring ones. Collections of text anthologies provided the sources here. Oskar Loorits collected materials in the first decades of the 20th century on the religious beliefs and verbal artistry of the moribund Livonian people (Loorits 1926-1928 reissued in 1998, 2000). His five-volume collection is the classical source of information on Livonian folk culture. Livonian beliefs concerning the sky and phenomena associated with it can be found in the first volumes, as well as fragments of myths and religious tales, which are compared to Estonian traditions. Calendrical traditions are found conversely in the fourth volume, which was published nearly forty years after the death of the author. It is in unpolished form and is not on par with his earlier works with their observations and many parallels made by the scholar in his younger days. Many of his other numerous works on folk beliefs were difficult to find. In Oskar Loorits' opinion many of the motifs in mythical songs are similar to ancient epics of Asia and they reflect original astral myths (e.g. Loorits 1949: 404). Of great value are the author's observations about Christian influences, for example the concept of heaven and its inhabitants as well as other phenomena more closely connected to astronomy. His extensive monograph on the fundamental ideas behind Estonian folk religion, nevertheless, focuses on the different conceptual aspects and forms of the soul (Loorits 1949-1957). Unfortunately, due to understandable reasons O. Loorits' ideas and works are still not completely available let alone during the period when archaeo-astronomy was developing. Here too we should mention descriptions of sacred/sacrificial sites by Richard Viidalepp (1940) and Oskar Loorits (1935). This theme was also addressed by M. J. Eisen (1922).

Even though Finnish folklorists had already ingeniously solved many of the outstanding questions connected with the mythological songs (see Kuusi 1963), and, while Oskar Loorits and Gustav Ränk, as well as other scholars living in exile, had seriously worked on questions around folk religion, this corpus of knowledge and relevant publications were generally unavailable.

The lack of information during the Soviet period was somewhat alleviated by the movement of books and all manner of written sources through an informal network of contacts. For example, ear- 
lier publications, materials sent from abroad as well as typewritten copies and translations of works unavailable through any other channels were disseminated through this network. The outlines for a series of lectures forming a work on Estonian religion, compiled in the 1930s by the theologian and folklore scholar Uku Masing (finally published in 1995) circulated for decades in manuscript form. The first part of this work gives a summary of the motifs found in the songs about creation as well as the variety of characters found in them and the variants of the same songs in Finnish traditions. Other astral phenomena are also dealt with, although the gods of the heavens and sky are represented by fiction on the part of the author and not authentic records. The various forms of the name of the god Taara and his parallels in many other languages was treated in more detail by the same author in a separate article (Masing 1939).

In short, by the 1960 s relevant thematic research in folklore had reached a stage where it was difficult to continue using existing methods.

\section{THE ROLE OF ARCHAEO-ASTRONOMY IN RESEARCH}

Culture by its very nature is a multi-layered communicative process. Just as the study of astral-mythology was initiated by Max Müller - among other things, the interpretation of astral myths was important for the structuralists - in the second half of the 20th century Heino Eelsalu (1930-1998) and the individuals interested in archaeo-astronomy, who had gathered around him, influenced the times they lived in and the whole of Estonian society. At that time their writings and the works of other key individuals probably did not leave one Estonian indifferent.

Heino Eelsalu was one of the central figures of the extensive research work that was started in the 1960s. His reconstructions of the calendar, sacred cult sites and astral mythology deserve separate treatment and the results of this work need to be re-evaluated by today's standards. Eelsalu's personal contribution in giving a sense of value to the many different areas of archaeo-astronomy and pre-history, a sense of interdisciplinarianism, cooperation among scholars from different disciplines and their participation in the 
study and popularisation of all this, is a phenomenon all its own. Below I wish to point out just a few of the research projects and how this movement was manifested in society. It must be emphasised that at that time this scholarly work was conducted without the benefit of any institutional support and was done on the part of the individuals involved in their own free time. Eelsalu, who has been mentioned here more than just once, is responsible for the largest number of written pieces, but among like-minded individuals there are many outstanding people highly-esteemed in their own fields. Physicists, astrophysicists, historians, archaeologists, geologists, agronomists, writers and artists proposed ingenious hypotheses and provided solutions to the problems. These include figures such as Heino Eelsalu, Paul-Egon Prüller, Vello Lõugas, Herbert Ligi, Enn Ernits, Väino Poikalainen, Tõnis Vint, Jaan Kaplinski, Lennart Meri, Kaljo Põllu, Ülo Stöör, Mikk Sarv and many others. Heino Eelsalu writes in his memoirs that at the conferences on Baltic history that started in 1958 he was struck by the expertise of several Latvian and Lithuanian scholars who had exhibited an interest in their ancient pre-history (Eelsalu 1993). As an astronomer and historian of science, he started to collect the vague research in the 1960s done by himself and other like-minded scholars around a so-called palaeo-astronomy research programme. In a later overview he noted that his programme coincided and strongly meshed with similar attempts on the part of individuals from the humanities sharing his views. And so it was. Palaeo-(archaeo)-astronomic research coincided with the growing national awareness of many creative artists as well as the period of time of experimentation with new ideas and methods. The activity between the 1960s and 1990s brought together many scholars from a variety of backgrounds as well as young novices into the ranks of academia, and artists who were interpreting folklore material and natural monuments with an especially liberated sense of creativity. Hypotheses were proposed concerning the prehistoric calendar, the connection between myths and palaeo-astronomy, astral motifs as reflected in the old runic songs, the orientation of graves and cult sites and much more. As an independent movement the copying and interpreting of rock art made strides. The meaning of the whole concept of being part of the Finno-Ugric world for Estonian culture was reevaluated. 


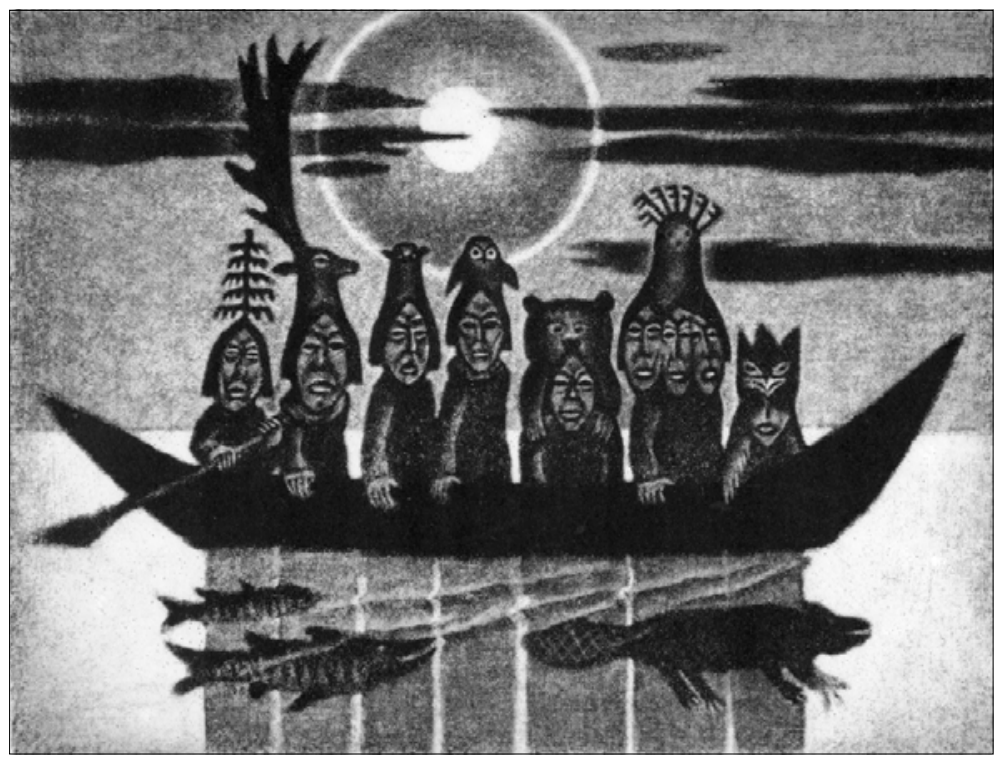

Photo 1. Kaljo Põllu's Kodalased (Ancient Dwellers) visualised ideals and the past. Reproduced here is a graphic sheetPäikesevene (The Sunboat) from the series (mezzotinto, $37 \times 49 \mathrm{~cm}, 1974)$.

The need to re-establish a collective social memory, be it a conscious or an unconscious movement, was central here. So too was creativity, which by definition is the opposite of cliché, the norm and the everyday (See Mikita 2001: 88).

In a private letter from 1975 Lennart Meri among other things stated: "I want to take a look at the cultural history of the Estonian people, one that is free from all inferiority complexes and the masochistic fawning resulting from 700 dark years of slavery" (Eelsalu 1993). L. Meri's candid evaluation sums up the aims of many writers of that time - to speak about Estonian history and society without the distortions and fragmentation of the Soviet treatment of it. The style and message in Meri's letter is typical of the messages and ideology of the first period of national awakening. Among these are, for example, the famous Kolm isamaalist konnet (Three Patriotic Speeches) of Carl Robert Jakobson from 1868-1870 (Jakobson 1991). These were attitudes that were published in journals, text- 
books and literature reflecting the nationalistic aspirations of the intelligentsia of the 19 th and early 20 th centuries. These same sentiments survived into the latter half of the 20th century through literature and similar rhetoric. The 700 dark years of slavery were later extended in the minds of the population to include the Soviet occupation and regime.

Archaeo-astronomy was mainly concerned with folk traditions and primarily around the interpretation of Estonian epic traditions. Mythic motifs were associated with cosmic phenomena and processes that were dated to tens of thousands of years ago. Runic songs became an important source, but many other areas of ethnic studies (such as ethnology, linguistics, Finno-Ugric studies) were used to reconstruct history. For example, Heino Eelsalu and Enn Ernits looked for connections between sacred cult rocks and the ancient starry sky, between the landscape and the reckoning of time as well as the general principles behind reckoning time (Eelsalu \& Ernits 1977, 1978; Eelsalu 1976a, 1976b, 1982, and others; see more specifically Kõiva \& Vesik 2005). Their treatment of the ancient calendar and the reckoning of time were based on the chronological overview of important red-letter days in the folk calendar and anthology of calendrical texts published in the 1970s (Lätt 1970; Hiiemäe 1981-1999; 1986). The connection between the symbols, colours, time reckoning and mythic motifs hidden in the folk songs were of interest to the brothers Mikk and Tõnn Sarv (Sarv \& Sarv 1979a, 1979b, 1980). The research work in the area of palaeo-art (Vint 1978, 1980; Põllu 1977, 1978a, etc.) was influential and supported these movements. Here symbols and marks were decoded, which raised the problem of the ancient symbolic writing system hidden in the decoration of ethnographic artefacts. In the field of archaeology the leading figure was the charismatic Vello Lõugas (1972, 1979, 1980a, 1980b). Today the reconstructions of the social background and rituals associated with archaeological finds from the prehistoric period are quite common if perhaps open to debate, but at that time they represented quite a new approach.

The field of meteor research was widened with the help of amateurs. The Kaali craters of Saaremaa became the significant source and concentration for archaeo-astronomical, archaeological, and linguistic observations and hypotheses. The falling of the meteor, pre- 
historic settlement patterns in Saaremaa, folklore and belief accounts were studied. Using all this the earlier prehistory of Estonia was re-evaluated.

In 1976 Lennart Meri's novel Hõbevalge (Silver White) was published with its subtitle "Travelogue on the Winds and Ancient Poetry", in which he proposed a hypothesis based on runic songs about the falling of the meteor, the ensuing explosion and concomitant fires that left its mark on Estonian and Scandinavian folklore, contemporary chronicles and historical sources, and its even wider effects on the European cultural area. The book contained references to the awe-inspiring pre-history of the Estonians, their relations with the Vikings and shed light on the earlier pre-Christian history of the settlement of Estonia from a new perspective. The amalgam in his presentation of a heroic and exciting world view, all the facts, hypotheses and fiction instantly became extremely popular and formed the basis for wide-ranging discussion. It was just this early pre-history and the contemporary cultural contacts, the question of an equal participation in the wider cultural areal of Europe and the influence that the people once living in this area had on their neighbours, that was a thorn in the side of the national mythology and self-awareness. The sequel that appeared in 1984, Hõbevalgem (Silverier White) with its subtitle "Travelogue on a Big Bang, the Wind and Ancient Poetry" was accompanied by wide readership acclaim. For many Estonians these books were handbooks of genuine history.

The nationalities' policy of the Soviets was one of fragmentation and segmentation. Estonian history was minimally taught, and many of the facts were distorted. For example, the Russians were portrayed as ancient allies, and understandably, the handling of more recent history was in particular not comprehensive. Officially there was only one amended and canonical written version of history. At the time when Estonian history had been marginalized and minimized, Lennart Meri's works now restored an honourable and aweinspiring history to the people.

To return to the Kaali meteor craters, which inspired many archaeoastronomers to further research, readers must be reminded of an article by Ago Aaloe in 1981 stating that the craters were 2000 years old, which was in all respects an appropriate time frame for associ- 
ating the meteor with the myths. Pre-historic farm fields are thought to be around the same age while the ancient indigenous runic songs are felt to be twice again as old (Peegel 1973). Currently, the actual estimation is that the craters date to between 9000 and $7500 \mathrm{BC}$, in other words to a time when the island of Saaremaa had very few inhabitants. Newer research now views the impact of the meteor explosion and its effect on the people living in the vicinity with some scepticism. The relatively recent retreat of the ice sheets, sparse population density and the fact that the places mentioned in Lennart Meri's theories were at that time on land that was just newly rising from the sea has not been able to diminish the hypothetic impact a falling meteor may have had on culture and human memory. This is demonstrated, for example, in the article recently released by Ain Haas and his co-authors about the Kaali craters and how it was reflected in human cultures (Haas \& Peekna \& Walker 2002). Hundreds of listeners gathered once again at the interdisciplinary conference for the reinterpretation of the Kaali phenomenon in 2003.

At this point we might ask why genealogies or rather genealogical lists are important for society. Is it for connecting people with their ancestors and in this way to legitimise their claim to the land and power? Other narratives explaining origins and successions can serve in a similar legitimising capacity, be these creation myths, stories explaining the origins of families or clans, the establishment of farms or other such texts. Tiiu Jaago has called at least a portion of these "stories of self-origin", which serve to give a community the right to own a concrete locality based on its earlier settlement history (Jaago 2002). Several of the above mentioned works might legitimately be classed as genealogic narratives, as are the stories of the expeditions to Rome by the warrior leaders of Saaremaa, the stories mentioned in the speeches and written overviews of $\mathrm{C}$. R. Jakobson about warriors equal to the Vikings or the imprisonment and execution of Scandinavian chiefs as well as written works speaking about mythic history. It is also believed that the original purpose of genealogies, in addition to legitimising land claim issues, was for the purpose of religious justification and the glorification of families. Thus, we can view the invention of a pre-history within the Soviet context as a means of creating an identity. In the case of the Estonians it was the creation of a social identity: who we are 
and where we come from. Certainly, it was in opposition to the sense of being without history, the fragmentation of history, the realisation of the danger of national annihilation. This was the creation of self-esteem, or in other words the creation of a satisfying history, which was achieved by means of a demonstration of the great age and glory of a national history.

\section{FIELDWORK - THE BASIS OF RESEARCH}

Fieldwork and practical experiments were the significant basis for the research in those days. Fieldwork was conducted among linguistically related peoples, at sites where rock art were found; archaeological remains were inspected, experiments were conducted with iron smelting, and meteors became a field of study. Different conservation programmes that continue to this day were started then.

Many sites had been uncovered already earlier. For example, a local farmer had already discovered the site of Asva fort in 1930. Only later did Vello Lõugas go there to do archaeological excavation. He subsequently became a leading expert in the archaeology and folklore of Saaremaa. The geologist Ivan Reinvald had already been sent to Saaremaa in 1927 to clarify the origins of the Kaali craters. The round lake in the main crater, with a depth of 1-6 metres and a diameter of 30-60 metres, was connected with legends of a mysterious nature. According to these, the lake had swallowed up a church, which had sunk to its bottom because of some taboo that had been violated. The steeple was still said to be visible in the water. There are also stories about a prohibition against measuring the depth of the lake, as well as other traditions. In 1960 the long-time researcher of the Kaali craters, Ago Aaloe, sought cooperation from astronomers, because he felt that in order to discover the origins of the craters an interdisciplinary approach was required. However, actual co-operation was set up with representatives of other fields. The collection of charcoal remains from the Kaali area inspired interest in studying early iron smelting and the local prehistoric settlement. The Kaali craters and archaeology of Saaremaa have provided interesting discoveries to this day, which have changed our perception of the social hierarchy and life of bygone days (see for 
example Mägi 2002). Many archaeological sites were uncovered by trying to find corroboration for vague stories found in folk traditions, place names and taboo sites. In addition, in the 1970s and 1980s the work on inspecting and establishing the orientation of the marks on the cup-marked stones as well as offering stones was started in Estonia (Eelsalu \& Hamel 1980). This work is now coming to fruition.

Even though the local traditions of Estonia were the preference, work was also done with neighbouring smaller Balto-Finnic peoples and later with collecting traditions from the Finno-Ugric and Uralic peoples. Again it is worth mentioning that in addition to institutional interest in this, visits to linguistically kindred peoples by volunteer researchers were inspired by the ideas current at the time. Paul Ariste spent decades collecting the traditions of the moribund Vote people. Enn and Tiiu Ernits, whose work continues to this day, compiled and wrote about the astral traditions of the Votes (Ernits \& Ernits 1984).

In 1978 under the leadership of Kaljo Põllu the Estonian Academy of Arts sent expeditions to preserve rock drawings and the ethnography of moribund Finno-Ugric peoples. General philosophical reflections based on the materials collected during the fieldwork can be found in the graphic art of Kaljo Põllu, in the graphic art and jewellery of Kärt Summatavet, as well as in the creative works of other participants in the expeditions. Such trips form an unbroken tradition of nearly thirty years (see Põllu 1990, 1999). Over the past few years these expeditions have been led by Kadri Viires. In addition to the collecting of ethnographic drawings by professionals, these expeditions have also provided an opportunity to expand the worldview of differing cultural areas and tie them together. Part of the mission of the 1980s was to leave copies of the recorded materials to local museums and communities. Annual exhibits of the material, overviews and conferences have become a permanent feature of today's cultural experience.

The Society for Prehistoric Art, under the direction of Väino Poikalainen, initiated expeditions for the purpose of preserving rock drawings. In the interests of this research, more exact methods for copying, measuring and mapping the sites were sought out. These expeditions have also continued for the past twenty years. The rich 
materials preserved by volunteer copyists and researchers on their annual summer expeditions have been presented and published internationally (for example Poikalainen \& Ernits 1998; Poikalainen 1999, etc.). All this activity, including conferences, expeditions and publishing has been the responsibility of the society to this day. As a result of the work of volunteers physical objects in the landscape were uncovered and described. Detailed measurements and copies of the drawings were also made. Using exact methods of analysis, hypotheses about the function and meaning of the drawings were tested. The preserved materials and statistical information about ancient monuments and sacred sites, drawings and markings as well as their orientation have resulted in an invaluable database.

\section{HOW MYTHS AND HYPOTHESES SPREAD}

One of the characteristic features of the Soviet period was that knowledge and the results of research were usually disseminated by means of lectures, either as private lectures at informal circumstances or using legal forums as lecture series of scientific societies. In addition to verbal communication, conferences were also an important means of presenting results and viewpoints, even though special departments of the security organs kept an eye on the organisation of such events. At the end of the 1970s and the beginning of the 1980s interdisciplinary archaeo-astronomic forums gained a hitherto unheard of interest on the part of the public. For example, at an event organised in 1977 under the guise of a scholarly history conference, the results of research on stone labyrinths were discussed and by 1979 such conferences were openly connected with palaeo-astronomy. The presentations were about early prehistory in the light of folk songs and myths, runic calendars, ancient calendrical systems and other topics. Unfortunately, the palaeo-astronomy conference of 1982 was the last in the series of such public events. It was difficult for the organisers to get official permission for the conference, and the official upset caused by the presentations as well as the reaction of the audience resulted in the abandonment of such events during the increasingly rigid Brezhnev regime. Even though public forums were no longer available, the media continued to release the results of fieldwork and the hypotheses. 
In the 20th century the media had become a significant influence on public mentality and opinion. For example, the thematic content of the programming for Estonian Radio speaks very vividly about its rapid politicisation. In the $1980 \mathrm{~s}$, at the height of the period of Russification and censorship, $67 \%$ of the programming was devoted to economic and other such publicly suitable themes (of this $23 \%$ was specifically devoted to politics and ideology), $22 \%$ to culture and $10 \%$ to sport. During the less controlled late-night programming however, only $5.4 \%$ was devoted to politics while $63 \%$ was devoted to culture (Lõhmus 2002: 80-82. Such cultural programming was one of the determining factors for the Zeitgeist of the times.

Only a part of any given class actually goes to conferences. Verbal communication, fed by events and the news, helps spread knowledge, but, at the same time, it causes shifts and noise. I believe that a very significant form of communication during the Soviet period was the so-called academic system, where a group of students would gather together with a teacher to listen to lectures and instruction. Here they discussed, philosophised, translated, gave reports, and conducted experiments under the teacher's tutelage. (For example, the artists around Kaljo Põllu, Kübarsepp 2004; Tõnis Vint's informal lectures still continue to this day. The present author had the fortune to attend discussion evenings at the homes of Mikk Sarv and others.)

The individuals involved with archaeo-astronomy and the principles of ancient culture were particularly successful in finding a voice in the printed media. Their short articles (the format of the publication determined the length) were published in popular scholarly journals such as Horisont (Horizon), as well as Eesti Loodus (Estonian Nature), Keel ja Kirjandus (Language and Literature), Looming (Creation) and others. At this point it must be mentioned that the contemporary media had much more prestige as compared to today. If today we can see a common trend in the media - i.e. visual information and the great influence of magazines on public opinion, the authority behind what is found there and belief in it (compare for example McQuail 2003) -, the relationship in the Soviet period was much more complex. Since journalism and the news that was reported therein was censored and distorted or altogether falsified, readers sought reality in the meta-text. Certain publications 


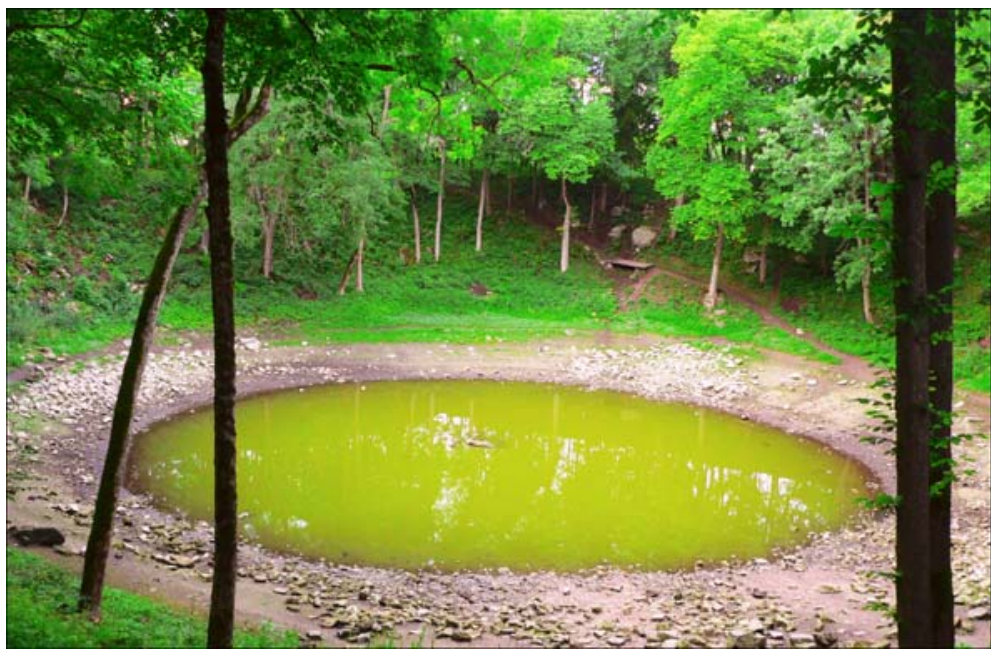

Photo 2. Lake Kaali - the cause for many myths. Photo by Andres Kuperjanov.

absolutely however, had a higher level of prestige and what was printed in these was received as scientifically proven fact. Scientific publications, including the ones already mentioned above, belonged to this group. Since the majority of myth making and interpreting appeared in publications with a very high believability quotient, the possibility of it being fictitious or hypothetical was precluded from the very start. Since the publication cycle in scientific journals was quite long and the circle of authors and themes a matter of mere choice, the archaeo-thematic researchers whose articles found their way into these publications can be considered very successful indeed.

Self-awareness was constructed as an amalgam of scholarship and creativity, oral and printed, high culture and folk culture. All these contained the same semantic message and created a colourful part of their own in culture, scholarship and self-awareness. The top works of the time were the experiments with ancient runic songs and chants by Veljo Tormis, the graphic series Kodalased (Ancient Dwellers) and Kalivägi by Kaljo Põllu, ballet master Ülo Vilimaa's experimental production of Kodalased, Uku Masing's lectures in 
Jaan Tooming's theatre studio and the essay on the worldview of boreal cultures that grew out of these (Masing 1989). This article was merely a list of references that attempted to point the way toward some universal statement about ancient times, since many individuals were making forays in that direction. And even though the integration of national ethnographic materials into high culture always creates a certain furore and opposition, what is clear is that the solutions were creative and the interpretations, unusual. In other words, a sufficient amount of creative material had been amassed to result in a shift in the cultural picture.

Without a doubt, works of art have a different, hidden, often deeper influence on the public than the works of scholars. An unfortunate example of this is the effect that Richard Wagner's creative credos as well as those of his disciples had on the contemporary interpretation of German mythology, which was reflected in the social and cultural picture and later clearly found its way into national ideology (see Lincoln 1999: 56). Lennart Meri with shocking frankness presented a picture of the early history of the indigenous FinnoUgric peoples of Russia in his films Veelinnu rahvas (Waterbird People) and Linnutee tuuled (Winds of the Miky Way). History, mythological similarities and the authors own hypotheses were interwoven in these films. Quite differently from his sincere and official writing on history, Meri with this approach in his films shook and managed to shift the understandings of scholars major centres in Russia. The unique role of artistic creations as well as Meri's books have already been mentioned above.

\section{RELATIONSHIPS WITH OFFICIAL SCHOLARSHIP}

In the 1960 s an attempt was made to establish a research centre that would unite representatives from a variety of different fields (see for example Moora 1956; Tampere 1956). This, however, was not successful. An interdisciplinary field presumes that both scholars as well as readers have a wide-ranging level of erudition, professionalism and knowledge of the methodologies of different fields. At the same time, it would be all too easy to overextend oneself beyond the boundaries of one's capabilities. 
No productive dialogue ensued for researchers from the field of archaeo-astronomy with the representatives from the official areas of scholarship. The creative arts, however, were very well received. The reasons for these differences arose from the different level of professional training, differences in methodology and worldview, different ways of treating problems in different periods of time and different ways of fulfilling the needs of society.

After the Second World War, research in mythology and ethno-astronomy shifted from the folklorists and philologists into the hands of physicists, astronomers from different branches and researchers in the field of the philosophy of science and others. Thus, to a certain extent it became a matter of whose guild belonged to what. Earlier I hinted that the basic works in folklore studies were generally available to the researches in these fields but new approaches in order to go beyond these limits were not available. One can only wonder why philologists over and again participated in such a conservative and lethargic fashion at the brain-storming sessions and analysis processes of those days. Instead, they outspokenly tried to quash any heated exploration of ideas (for example Eelsalu \& Stöör 1984) or remained silent rather than actively take part. Perhaps the reason was that the majority dealt with runic songs. Of them, only two or three had become scholars dealing with stories and folk religion, and their hands were too tied up or the subject matter too distant.

The way that the generalities behind verbal texts were taken into account and the methodologies what one could or could not gain from them were different. This includes the fact that a verbal text might reflect some real topographic feature or historic event, but it did not mean that these were necessarily true facts. For the most part, contemporary folklore dealt with materials from the 19th and early 20 th centuries. On the basis of this material the earlier form and development of a given phenomenon were reconstructed. One could not go very far back in time this way. Characteristically the temporal boundary for dating a phenomenon was either pre-Christian (pagan) or Christian. In order to prove any given opinion crossreferencing was used: in other words, the age of any folklore phenomenon was established by referring to linguistic and archaeological hypotheses and periodizations while at the same time ar- 
chaeology relied on folkloric and linguistic evidence. In addition to the contemporary paradigm, the geographic spread of any given phenomenon was also important, as well as the relationships between the centre and the periphery, local differences, and influences from neighbouring regions. Where texts were concerned the numbers and how representative they were was also taken into consideration. A formalistic analysis of the poetics was widespread, but it provided no answer to the question of their function and motivation. The lists of alliterative devices and analyses of metres of the ancient songs were never brought together. The majority of studies used the methodologies of either, comparative, phenomenological, historical/comparative, historical/geographic schools of thought. Astral traditions, however, are part of a much larger system, be this one a folk religious one, a complex of rituals or folklore.

Archaeo-astronomy, on the other hand, relied on fieldwork and the choice of texts was completely different. The most expressive texts rather than whole corpuses of texts were used. Nineteenth-century texts were associated with extremely ancient times and cosmic processes. These were used to explain global generalities. A researcher's choice of a single text was often enough to prove a hypothesis. There was no question of how representative the text was, its authorship or even how genuine it was. The language of the runic songs and the metaphors of folklore were actually believed to describe astral events. The use of resource materials was quite open whereas a precision with respect to the physical objects and natural phenomena themselves was demanded. In short, folklore was seen to be an all-encompassing phenomenon, in which universal generalities hold true. Heino Eelsalu's own personal priority was to see how astronomic universals were reflected in mental creative processes, or, in other words, he went from the viewpoint that the myths and mythic songs had recorded and conserved events, including changes in the starry sky, from tens of thousands of years ago and transmitted them in their own symbolic language.

As was mentioned, an interdisciplinary researcher can often fall into the trap where facts and their proofs do not necessarily follow one from the other in closely related disciplines, for example folklore, ethnography, linguistics and other fields. The research can thus unknowingly violate acceptable boundaries. H. Eelsalu for exam- 


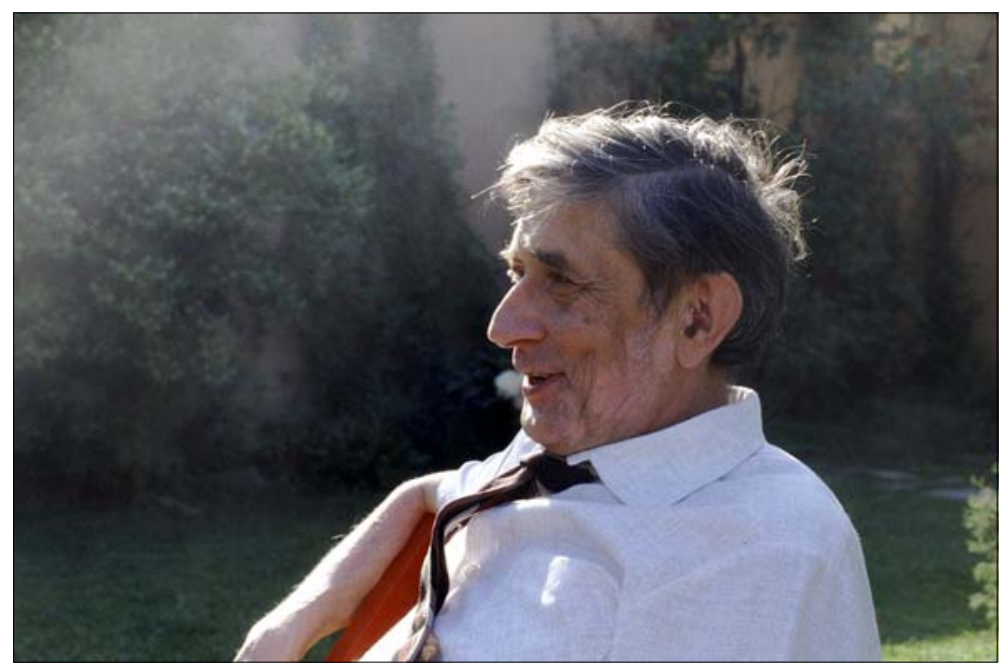

Photo 3. Heino Eelsalu (1930-1998) among his friends, recorders of rock art. Photo by Erkki Suonio.

ple, compared a Japanese calendrical feast with an artificial legend about dawn and dusk which had been created in the 19th century by Friedrich Robert Faehlmann (1798-1850) in order to establish proof for one of his theories (Eelsalu 1991). He considered this artificial legend to be representative of an ancient Estonian myth. His whole subsequent argument was based on this. This is merely one example of misguided interdisciplinarianism, similar example of which can be found in the histories of science and scholarship of many peoples.

Archaeo-astronomy did not develop in isolation. It is known that Eelsalu had contacts with archaeo-astronomers in Europe with whom he exchanged research and ideas. He used the results of Finnish researchers in his interpretations of myths and was familiar with Hamlet's Mill (Santillana \& Dechend 1969) and presumably other similar works. The preserving and interpreting of rock art have over the years significantly relied on the efforts of Finnish, 
Carelian, and Russian volunteers and scholars as well as international connections.

Although the effects that the starry sky has on today's people and cultures might have been an actual object of research, the vast majority concentrated on the past and the representation of the world view of that time as the object of interest. This latter is understandable given that in the second half of the 20th century those interested in the subject matter had access to non-European traditions, certainly much more extensive than at any time earlier, since the traditions of indigenous peoples collected during the course of fieldwork by anthropologists resulted in a wide-ranging opportunity to compare cosmogonic myths and beliefs. The myths, ritual practices and new publications introducing the belief systems of indigenous peoples were also being published in Russia in those days. All this was also used to reconstruct the phenomena of Estonian culture. More often than not, the interest in ethno-astronomy was motivated in connection with studies in mythology, but in the 20th century it

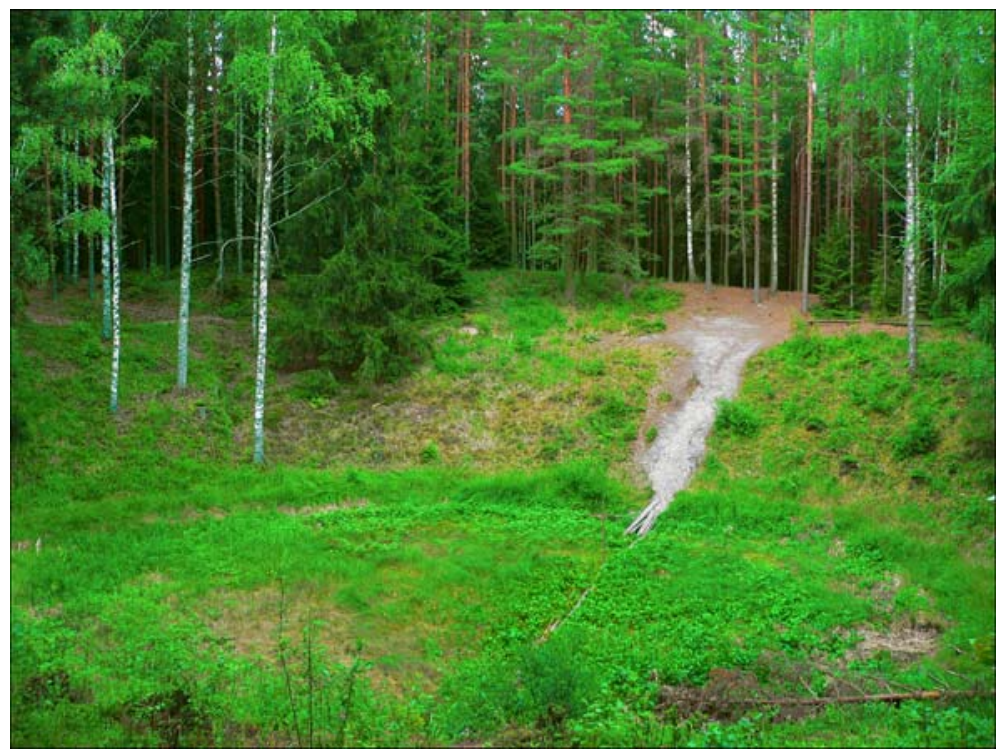

Photo 4. The meteorite craters at Ilumäe, Põlvamaa, though fascinating for both researchers and tourists, have almost no reflection in oral heritage. Photo by Andres Kuperjanov. 
was also sparked by the examination of models of belief systems and daily behaviour.

Researchers outside institutions were free to find areas of study even though the time and resources available to them were much more limited. In any case, it was easier for freelancers to follow their own calling and fulfil societal needs in comparison to the folklorist shackled by the orders from the state organs to research runo songs. The new national awakening, the interest the community had in its own history and the older layers of traditional culture, the spontaneous search for a national identity demanded immediate answers and the wider familiarisation of discoveries made to date. All this guaranteed continued public interest in archaeo-astronomic publications and conferences.

\section{CONCLUSION}

Which is more important in history - the event or its structure? Thus ponders Peter Burke as he weighs the newer treatments of history. He feels that as times change, so do the narratives about history. Certainly there will be a movement away from presenting historical events in the opposite direction, and appropriate ways of connecting different ways of treating history will be found (Burke 2001). Which is more important in archaeo-astronomy - significant discoveries and research or making them more widely known in the society so that they will be of interest to the public and they will influence public understanding of history and worldview? Presumably both are relevant.

In the Baltic region archaeo-astronomic research and its manifestations had an influence on the search for identity and national awakening that in Estonia began in the 1960s. One of the more interesting aspects of this was the interpretation of archaeo-astronomic phenomena in the light of archaic mythic motifs. Interdisciplinarianism, creativity and the amalgamation of many different spheres were powerful. The public followed the results of research with keen interest, even if at times the research was presented in a complicated fashion and was not easy to read. Still, the conferences were well attended. Interest in archaeo-astronomy and its outcomes in the society at that time were comparable to today's 
bestsellers. It was sincere, immediate and very widespread. People took interest in the national intellectual heritage and their roots, so to speak. Presumably, the creativity and results from archaeoastronomy helped to widen the abstract approaches, levels of generalisations and creativity in many different disciplines. The wealth of ideas at that time was especially fruitful in the arts.

Inevitably, all research activity is to a certain extent cyclical. As one methodology sinks into oblivion, there arises a need to re-evaluate the sources and results of the past using new methods. Since the 1990s research in the humanities on mythology and folk religion, sacred sites and much more, has continued. This is demonstrated by the wide gamut of ideas and their publication in the form of monographs (see in more detail Kõiva \& Vesik 2005). Comprehensive discipline-specific research provides an excellent foundation for interdisciplinary research. It would be very difficult to come up with broader generalisations if, for example, the work of cataloguing the names of various stars had not been done beforehand or if the systematic ethnographic descriptions of various phenomena were missing. There is still much work to be done on building a fundamental base of ethnographic material. Unfortunately, often there are too few records of phenomena. Instead, there is much more in the nature of newly created myths on the part of the authors writing in the 19th and 20th centuries. Andres Kuperjanov has stated concerning the corpus of knowledge about Estonian folk astronomy that collection by naive individuals, the wrong choice of time frame for the survey, inaccuracies, relying solely on memory as well as influences from school and literature has stunted the knowledge of folk astronomy (Kuperjanov 2002). In fact, official astronomy and the media have eclipsed the knowledge of folk astronomy among many peoples in Europe.

There are many aspects, which we cannot collect in their pristine archaic form. Moreover, people today also have quite odd ideas about the structure of the universe. The work of describing how cosmologic research is manifested in beliefs and narratives is to a great extent still before us. Exceptionally, there are collections of texts about UFOs that have been influenced by science fiction published for many different types of readers. The gamut ranges from pseudo- 
and alternative science to hard science. The bibliography of thematically relevant folklore articles itself constitutes a lengthy volume. This includes media and pop culture as well.

Ten years after the period of interpretations of archaeo-astronomic material it would be appropriate to present a summary of the writings of Heino Eelsalu and many other enthusiasts and evaluate them. What part of this can be incorporated in "beginning level courses" and what belongs to folk mythology and master narratives. These were two areas that were created and supported most successfully in those days (see an attempt toward this for example Kuperjanov 2005: $101 \mathrm{ff}$.).

That archaeo-astronomy is relevant is confirmed by the fact that each year at least one prophet proclaiming the end of the world arises, some people who want to use old sacred sites or build new ones emerge, and present new versions of ancient astral phenomena. And now, to come back to what has been repeated earlier; so much work has already been done in so many areas that it is high time to start working on a comprehensive concordance of everything, unifying the results of the research and summarising it.

The type of archaeo-astronomy that in the 1960s to the 1990s sustained Estonian society no longer exists. The collecting of facts and writing about them on top of day-to-day work and study as well as the restrictions and stress of the Soviet period did not allow many writers to develop or refine their writing. However, there were aweinspiring and unexpected results such as for example young enthusiasts and researches who grew up in the previous wave of interest and cultural environment, who in their scholarly activities (or in the arts as well) are continuing work in archaeo-astronomy and related fields on a new level. A re-awakening of interest in mythology and archaeology is being fanned by a more general rising wave of mythology, be these from the humanities, an interest in early or medieval history, a re-awakening of a need to seek out an identity or perhaps supported by J. R. R. Tolkien, science fiction or inspiration from some other source. Charismatic scholars, interesting discoveries and hypotheses are still kindling an interest in archaeology. The circle has come full round and a new one is starting. 


\section{Acknowledgements}

This article is supported by a grant from ESF 5117. It is part of a longer piece called Merest, tuulest ja muinasluulest (About Sea, Wind and Ancient Poetry). Translated into English by Harri Mürk.

\section{References}

Aaloe, Ago 1981. Erinevused Kaali kraatrite vanuse määrangutes [Differences in Dating the Age of Estonian Craters]. Eesti Loodus, 4, pp. 236-237.

Burke, Peter 2001. History of Events and the Revival of Narrative. Burke, Peter (ed.). New Perspectives on Historical Writing. 2nd edition. University Park (Pennsylvania): University of Pennsylvania Press, pp. 283-300.

Cohen, Abner 1974. Two-Dimensional Man: An Essay on the Anthropology of Power and Symbolism in Complex Society. Berkeley: University of California Press.

Eelsalu, Heino 1976a. Kalendrikorralduse põhietapid [Main Stages in Organising the Calendar]. Eesti Loodus, 5, pp. 319-323.

Eelsalu, Heino 1976b. Missugune oli meie esivanemate päikesekalender ja millal ta kujunes? [What was the Sun Calendar of Our Ancestors Like and when Did It Develop?]. Eesti Loodus, 12, pp. 796798.

Eelsalu, Heino 1982. Kommentaar: ...ja tehislohkudega kivide otstarbest üldse [Comment: ... and on the Purpose of Artificially CupMarked Stones in General]. Eesti Loodus, 5, pp. 319.

Eelsalu, Heino 1991. Koit ja Hämarik ning tanabata-õhtu [Dawn and Dusk and tanabata-Evening]. Keel ja Kirjandus, 8, pp. 489-490.

Eelsalu, Heino 1993. Sõnumilt sõnumile: Meenutusi ja hinnanguid: Paleokultuuri uurimine Eestis 1960.-80ndail [From Message to Message: Some Memories and Opinions: Research of Paleo-Culture in Estonia in the 1960 s to 1980 s]. Looming, 12, pp. 1681-1690.

Eelsalu, Heino \& Ernits, Enn 1977. Mida aimame esivanemate kuukalendrist [What Inklings We have of Our Ancestors' Moon Calendar]. Eesti Loodus, 12, pp. 779-781.

Eelsalu, Heino \& Ernits, Enn 1978. Keeleandmed soome-ugri varase kalendriloo pidepunktidena [Language Data as Pointers in Early FinnoUgric Calendar History]. Keel ja Kirjandus, 5, pp. 280-282.

Eelsalu, Heino \& Hamel, Jürgen 1980. Väikeste tehislohkudega kivid ja paleo-astronoomia [Small Artificially Cup-Marked Stones and PaleoAstronomy]. Eesti Loodus, 6, pp. 379-381. 
Eelsalu, Heino \& Stöör, Ülo 1984. Looduse värvid ja loomise lugu [The Colours of Nature and the Story of Creation]. Eesti Loodus, 3, pp. 156158.

Eisen, Matthias Johann 1919. Eesti mütoloogia [Estonian Mythology]. Tallinn: Eestimaa Kooliõpetajate Vastastiku Abiandmise Seltsi raamatukauplus.

Eisen, Matthias Johann 1922. Esivanemate ohverdamised [Sacrifices of Our Ancestors]. Eesti mütoloogia, 3. 3rd, improved edition. Eesti Kirjanduse Seltsi Toimetused, 19. Tallinn: Varrak.

Ernits, Tiiu \& Ernits, Enn 1984. Vadjalaste ja isurite tähelepanekuid taevakehade kohta [Votians' and Izhorians' Observations on Heavenly Bodies]. Eesti Loodus, 9, pp. 577-581.

Haas, Ain \& Peekna, Andres \& Walker, Robert E. 2002. Echoes of Ancient Cataclysms in the the Baltic Sea. Folklore. An electronic Journal of Folklore 23, pp. 49-85. http://www.folklore.ee/folklore/vol23/echoes.pdf

Hiiemäe, Mall 1986. Aastajaotustähistest eestlaste rahvakalendris [On the Markers Dividing the Year in the Estonian Folk Calendar]. Keel ja Kirjandus, 2, pp. 90-96.

Hiiemäe, Mall (comp.) 1981-1999. Eesti rahvakalender [Estonian Folk Calendar], 2-8. Tallinn: Eesti Raamat.

Hurt, Jakob 1989. Eesti astronomia: Kõne Eesti Jaani koguduse Noortemeeste Seltsis 10. jaanuaril 1899 [Estonian Astronomy: A Speech in the Young Men's Association of the Estonian Jaani Congregation, on January 10, 1899]. Mida rahvamälestustest pidada: Artiklite kogumik. Tallinn: Eesti Raamat, pp. 91-130.

Iwanisczewski, Stanislav 1994. Cultural Astronomy in Europe. Archaeo-astronomy \& Ethnoastronomy News, 11. http://www.wam.umd. edu/\%7Etlaloc/archastro/ae11.html

Jakobson, Carl Robert 1991. Kolm isamaa kõnet: Kriitiline väljaanne käsikirjast kommentaaride ja järelsõnaga [Three Speeches of Fatherland: A Critical Edition of the Manuscript with Comments and Afterword]. Põldmäe, R., et al. (eds.). Tallinn: Eesti Raamat.

Jaago, Tiiu 2002. Kodu mõiste muutumisi 20. sajandil [Changes in the Meaning of the Term "Home" in the 20th century]. Jaago, Tiiu \& Kõiva, Mare (comps.). Dialoog privaatse ja avaliku elu vahel: Inimese ja keskkonna suhete peegeldus pärimuses, elektrooniline konverents. Täienduskoolituskursus: 18.02.-18.05.2002. Tartu: Eesti Kirjandusmuuseum, pp. 88-98.

Kuperjanov, Andres 2002. Killukesi Lõuna-Eesti taevapärimusest [Shards of South-Estonian Sky Lore]. Ojamaa, Triinu (ed.). Paar sammukest XIX: Eesti Kirjandusmuuseumi aastaraamat. Tartu: Eesti Kirjandusmuuseum, pp. 63-85.

Kuperjanov, Andres 2003. Eesti taevas. Uskumusi ja tõlgendusi [Estonian Sky. Beliefs and Interpretations]. Tartu: A. Kuperjanov. 
Kuperjanov 2005. Archeoastronomy in Estonia. Kõiva, Mare \& Vesik, Liisa \& Pustylnik, Izold (eds.). Cosmic Catastrophies: A Collection of Articles. Tartu: Eesti Kirjandusmuuseumi rahvausundi ja meedia rühm, pp. 101-106.

Kuusi, Matti 1963. Suomen kirjallisuus I: Kirjoittamaton kirjallisuus [Finnish Literature I: Oral Literature]. Helsinki: Suomalaisen Kirjallisuuden Seura.

Kõiva, Mare \& Vesik, Liisa 2005. Linguistic and Folkloristic Aspects of Prospective Research in Archeoastronomy. Kõiva, Mare \& Vesik, Liisa \& Pustylnik, Izold (eds.). Cosmic Catastrophies: A Collection of Articles. Tartu: Eesti Kirjandusmuuseumi rahvausundi ja meedia rühm, pp. 87100 .

Kübarsepp, Riin 2004. Visuaalse rahvaluule kollektsionäär Kaljo Põllu [Kaljo Põllu, Collector of Visual Folklore]. Mäetagused: Hüperajakiri, 29, pp. 31-74. http://www.folklore.ee/tagused/nr29/pollu.pdf

Lincoln, Bruce 1999. Theorizing Myth: Narrative, Ideology, and Scholarship. Chicago \& London: University of Chicago Press.

Loorits, Oskar 1926-1928 Liivi rahva usund [Livonian Folk Belief], I-III: Mit einem Referat: Der Volksglaube der Liven. Acta et Commentationes Universitatis Tartuensis (Dorpatensis) B: XI: 1, XII: 1, XVI: 1 = Tartu Ülikooli toimetused B: Humaniora 11: 1, 13: 1, 16: 1 = 1998. Tartu: Eesti Keele Instituudi rahvausundi töörühm. http:// www.folklore.ee/rl/pubte/ee/lru

Loorits, Oskar 1935. Mulgimaa ohvrikohad [Sacrificial Sites in Mulgimaa]. Kaleviste mailt. Ôpetatud Eesti Seltsi kirjad, 3. Tartu: Õpetatud Eesti Selts, pp. 225-300 [Zusammenfassung: Die Opferstätten in Mulgimaa, pp. 315-319].

Loorits, Oskar 1949-1957. Grundzüge des estnischen Volksglaubens, I-III. Skrifter Utgivna av Kungl. Gustav Adolfs Akademien för Folklivsforskning 18: 1-3. Lund: Carl Blom.

Loorits, Oskar 2000. Liivi rahva usund [Livonian Folk Belief], IV-V. Tartu: Eesti Kirjandusmuuseum. http://www.folklore.ee/rl/pubte/ee/lru

Lotman, Juri 1991. Kultuurisemiootika: Tekst - kirjandus - kultuur [Cultural Semiotics: Text - Literature - Culture]. Tallinn: Olion.

Lowenthal, David 1996. Possessed by the Past: The Heritage Crusade and the Spoils of History. New York: Free Press.

Lowenthal, David 1998. Fabricating Heritage. History and Memory, 10. http://www.iupress.indiana.edu/journals/history/ham10-1.html

Lõhmus, Maarja 2002. Transformation of Public Text in Totalitarian System: A Socio-Semiotic Study of Soviet Censorship Practices in Estonian Radio in the 1980s. Turun Yliopiston julkaisuja. Annales Universitatis Turkuensis, B: 238. Humaniora. Turku: Turun Yliopisto.

Lõugas, Vello 1972. Väikeste lohkudega kultusekivid [Cult Stones with Small Depressions]. Eesti Loodus, 12, pp. 729-732. 
Lõugas, Vello 1979. Kaali: legendid ja leiud [Kaali: Legends and Finds]. Horisont, 9, pp. 13-17.

Lõugas, Vello 1980a. Kõuekividest ja piksenooltest "vaia rahvani" [From Tunderstones and Thunderarrows to "People of the Stake"]. Horisont, 3, pp. 14-16.

Lõugas, Vello 1980b. Nagu välk selgest taevast [Like a Flash from a Clear Sky]. Horisont, 4, pp. 40-45.

Lätt, Selma (comp.) 1970. Eesti rahvakalender [Estonian Folk Calendar], I. Tallinn: Eesti Raamat.

Masing, Uku 1939. Taara päritolust [On the Origin of Taara]. Usuteaduslik ajakiri, 9 (1), pp. 1-16.

Masing Uku 1989. Taevapõdra rahvaste meelest ehk juttu boreaalsest hoiakust [On the Minds of the Peoples of the Heavenly Reindeer, or on Boreal Attitudes]. Akadeemia, 1, pp. 193-223; 2, pp. 419-448; 3, pp. 641672; 4, pp. 865-895.

Masing, Uku 1995. Eesti usund [Estonian Folk Belief]. Tartu: Ilmamaa.

McQuail, Denis 2002. McQuail's Mass Communication Theory. Sage Publications Ltd.

Meri, Lennart 1976. Hõbevalge: Reisikiri tuultest ja muinasluulest [Silver White: Travelogue on the Winds and Ancient Poetry]. Tallinn: Eesti Raamat.

Meri, Lennart 1984. Hõbevalgem: Reisikiri suurest paugust, tuulest ja muinasluulest [Silverier White: Travelogue on a Big Bang, the Wind and Ancient Poetry]. Tallinn: Eesti Raamat.

Mikita, Valdur 2001. Loovad kultuurid või loovad inimesed [Creative Cultures or Creative People]. Kõnno, Andres \& Raitviir, Ain (eds.). Acta Semiotica Estica, I. Tartu: Eesti Semiootika Selts, pp. 82-97.

Moora, Harri 1956. Eesti rahva ja naaberrahvaste kujunemisest arheoloogia andmeil [On the Emergence of the Estonian and Neighbouring Nations on Archaeological Data]. Moora, Harri (ed.). Eesti rahva etnilisest ajaloost:Artiklite kogumik. Tallinn: Eesti Riiklik Kirjastus, pp. 41-119.

Mägi, Marika 2001. At the Crossroads of Space and Time: Graves, Chan-ging Society and Ideology on Saaremaa (Ösel), 9th-13th Centuries $A D$. CCC papers, 6. Tallinn: Visby University Colleague \& Institute of History, Tallinn.

Peegel, Juhan 1973. Pilk imepärasesse sõnavaramusse [A Look into a Wonderful Vocabulary]. Looming, 1, pp. 154-157.

Poikalainen, Väino \& Ernits, Enn 1998. Rock carvings of Lake Onega: The Vodla region. Tartu: Estonian Society of Prehistoric Art.

Poikalainen, Väino 1999. Some Statistics About Rock-Carvings Of Lake Onega. Folklore: An electronic Journal of Folklore, 11, pp. 60-69. http:// www.folklore.ee/folklore/vol11/carvings.htm 
Prüller, Paul-Egon 1968. Eesti rahvaastronoomia [Estonian Folk Astronomy]. Teaduse ajaloo lehekülgi Eestist 1: Kogumik. Tallinn: Teaduste Akadeemia Kirjastus, pp. 9-70.

Põllu, Kaljo 1977. Geotsentrilise maailmapildi kajastumine eesti rahvakunstis [Reflection of the Geo-Centric World View in Estonian Folk Art]. Eesti Loodus, 4, pp. 216-223.

Põllu, Kaljo 1978a. Eesti rahvaornamendi algkujundid [Prime Figures of Estonian Folk Ornament]. Eesti Loodus, 12, pp. 781-788.

Põllo, Kalju 1978b. Kodalased: 13 reproduktsiooni [Ancient Dwellers: 13 reproductions]. Tallinn: Kunst.

Põllu, Kalju 1988. Kalivägi: 25 reproduktsiooni metsotintosarjast, 1978-1984 = 25 reproductions of the mezzotint series "Kalivägi", 19781984. Tallinn: Kunst.

Põllu, Kaljo (comp.) 1990. Tallinna Kunstiülikooli kümme soome-ugri uurimisreisi = Tallinn Art University's Ten Expeditions to the FinnoUgrians. Tallinn: Olion.

Põllu, Kaljo 1999. Eesti Kunstiakadeemia kakskümmend soome-ugri uurimisreisi = Estonian Academy of Arts Twenty Expeditions to the FinnoUgrians. Tallinn: Olion.

Santillana, Giorgio de \& Dechend, Herta von 1969. Hamlet's Mill: An Essay Investigating the Origins of Human Knowledge and its Transmission through Myth. Boston: Gambit.

Sarv, Mikk \& Sarv, Tõnn 1979a. Suur Tamm ja Linnutee [The Great Oak and the Milky Way]. Eesti Loodus, 1, pp. 30-33.

Sarv, Mikk \& Sarv, Tõnn 1979b. Loomise lugu [The Story of Creation]. Eesti Loodus, 7, pp. 449-452.

Sarv, Mikk \& Sarv, Tõnn 1980. Hanede kadumise lugu [The Story of the Disappearing Geese]. Eesti Loodus, 10, pp. 661-664.

Tampere, Herbert 1956. Mõningaid eestlaste etnilise ajaloo küsimusi suulise rahvaloomingu valgusel [Some Questions of the Ethnical History of Estonians in Light of Oral Folklore]. Moora, Harri (ed.). Eesti rahva etnilisest ajaloost: Artiklite kogumik. Tallinn: Eesti Riiklik Kirjastus, pp. $255-277$.

Viidalepp, Richard 1940. Iseloomustavat Eesti ohvrikividest [Characterization of Estonian Sacrificial Stones]. Tartu: Eesti Rahvaluule Arhiiv.

Vint, Tõnis 1978. Kirivööd [Patterned Belts]. Kultuur ja Elu, 6, pp. $58-61$.

Vint, Tõnis 1980. "Kapsarauast” ja universumi kahest mütoloogilisest algjõust [On the "Cabbage Iron" and the Two Mythological Primal Forces of the Universe]. Horisont, 1, pp. 29-33.

Wallace, Anthony F. C. 1968. Nativism and Revivalism. Sills, David Lawrence (ed.). International Encyclopedia of the Social Sciences, 11. New York: MacMillan, pp. 75-80. 